\title{
"THE PRINCIPLE IS GOOD. THE WAY IT IS IMPLEMENTED is Bad." Challenges of the European Rural Development Policy in Romania
}

\author{
Kinga Xénia HaVAdI-NAGY, Cluj-Napoca*
}

\section{Content}

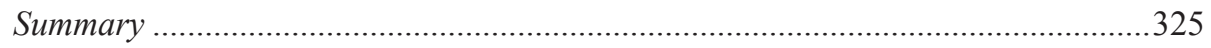

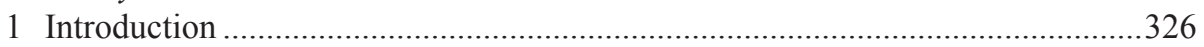

2 EU Rural Development Policy for the programming period 2007-2013 .............327

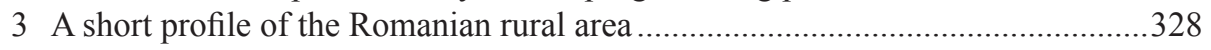

4 The Rural Development Plan of Romania for the programming

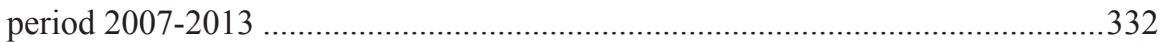

5 "The principle is good. The way it is implemented is bad." ...............................333

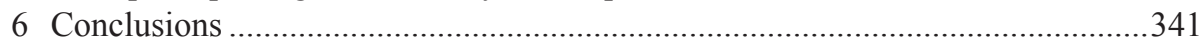

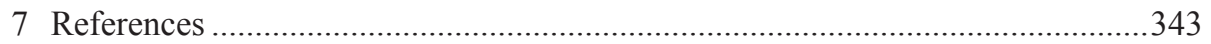

\section{Summary}

Independent of definitions applied - the Organisation of Economic Development and Cooperation's (OECD) regional typology or the national definition - most of Romania's territory is rural hosting about half of the total population. Sustainable development of these areas should therefore be a priority in national development strategies. This paper acknowledges the noticeable upgrade of living standards and substantial progress by the extension of various infrastructures and services in rural areas. However, it intends to outline some of the difficulties Europan Union (EU) Rural Development Policy faces currently in Romania, particularly in maximising synergies between and within the development axes and avoiding contradictions.

* Kinga Xénia Havadi-Nagy, Lecturer, PhD. Faculty for Geography at the Babeş-Bolyai University, Strada Clinicilor 5-7, RO-400006, Cluj-Napoca, Romania; email: xenia.havadi@, geografie.ubbcluj.ro 
It is a well-known fact that in case of improper and uncoordinated application, the existing generic EU policies can potentially counteract and thwart each other in their implementation, to the detriment of landscape quality, environment, economy and society. This paper illustrates the situation of rural Romania, where an insufficiently defined development vision for the programming period 2007-2013 rather hindered comprehensive and more efficient sustainable progress to the general benefit of the population.

After a short presentation of the EU Rural Development Policy for the investigated programming period (2007-2013), the paper depicts a short profile of the Romanian rural area and outlines the priorities of the National Plan for Rural Development. Following a selection of development priorities, it focuses on areas where improvement or even a shift in the development path is recommended, at the same time reflecting upon the solutions and alternatives facilitated by civil society organisations concerning in particular environment, small farmers and competitiveness. This paper concludes with an outlook on the seemingly improved development policy for the current programming period.

\section{Introduction}

Having joined the European Union (EU) in 2007, Romania is not yet celebrating ten years of membership, but concluded its first programming period as a member state of the EU. Accession to EU was a significant moment in the multiple - political, economic, and social - transitions Romania is experiencing in the last 25 years, associated with complex challenges affecting its society, economy and environment. Considering that $47.2 \%^{1}$ (NIS 2012) of the Romanian population is living in rural areas representing $87.1 \%$ (NIS 2012) of the total territory, it is obvious how vitally important development and support of rural areas in Romania is/should be.

Generally speaking, visible improvement of living conditions and progress in development and implementation of various infrastructure and services in the rural area is not contested. However, this paper intends to outline some of the challenges EU Rural Development Policy faces currently in Romania, in particular in maximising synergies between and within the axes and avoiding potential contradictions.

\footnotetext{
The national definition of rural area is dictated by Law 350/2001 referring to urban and regional planning and Law 351/2001 considering the National Plan of Land Use Regulation. It defines the rural area of Romania as consisting of 2,861 communes (31 December 2011) with administrative responsibilities matching EU NUTS-5. These are composed by several villages (totally 12,957) without any administrative functions. In compliance with the Organisation of Economic Development and Cooperation (OECD) definition the territory of Romania is 59.8\% rural (hosting $45.5 \%$ of the population), $39.4 \%$ intermediary ( $43.9 \%$ of the total population) and only $0.8 \%$ is urban ( $10.6 \%$ of the population living here). Existing statistical data refer to national definitions.
} 
After a short presentation of the EU Rural Development Policy for the investigated programming period (2007-2013), the paper depicts a short profile of the Romanian rural area and outlines the priorities of the National Plan for Rural Development (NPRD). Following a selection of development priorities, it focuses on areas where improvement or even a shift in the development path is recommended, at the same time reflecting upon the solutions and alternatives facilitated by civil society organisations regarding in particular environment, small farmers and competitiveness. This paper concludes with an outlook on the supposedly improved development policy for the current programming period (2014-2020).

\section{EU Rural Development Policy for the programming period 2007-2013}

As stated again in the Rural Development Strategy for 2007-2013, strengthening of EU rural development policy is an overall EU priority. This is not astonishing considering that for the studied period - according to the OECD regional typology adopted by the EU - over $90 \%$ of the EU-27 territory was "rural" and this area hosted over $60 \%$ of the EU's population. This situation got reinforced with the accession of Croatia in 2013. Numerous rural areas face significant challenges in building up competitiveness, since commonly average income per head is lower than in urban areas, while the skill base is narrower and the service sector is less developed. On the other hand, the European countryside has an exceptional offer, not only due to its great variety of landscapes and raw materials. Farming and forestry are significant also for land use and the management of natural resources. It also constitutes a platform for economic diversification in rural communities (EUROPEAN COMMISSION 2008). This is why the EU's Lisbon Strategy for job creation and growth and its Goteborg Strategy for sustainable development are just as relevant to the countryside as to towns and cities. Rural development is a vitally important policy area on the EU level and aims meeting the challenges faced by rural areas and revealing their potential.

In accordance with the enhanced significance of rural areas, EU Rural Development Policies promote their sustainable development. The Development Strategy for the programming period 2007-2013 - which concerned also Romania as a member state - focused on three commonly agreed core policy objectives (EUROPEAN Commission 2008):

(1) improving the competitiveness of agriculture and forestry. The resources devoted to this objective were intended to contribute to a strong and dynamic European agrifood sector by focusing on the priorities of knowledge transfer, modernisation, innovation and quality in the food chain, and on priority sectors for investment in physical and human capital. 
(2) supporting land management and improving the environment. To protect and enhance EU's natural resources and landscapes in rural areas, resources accessible through Axis 2 should have enhanced three priority areas: biodiversity and the preservation and development of high naturevalue farming and forestry systems and traditional agricultural landscapes; to support water quality management and to cope with consequences of climate change.

(3) improving the quality of life and encouraging diversification of economic activities. The resources allocated to Axis 3 were aimed to facilitate the creation of employment opportunities and conditions for growth. The range of measures available under Axis 3 should have been primarly used to promote capacity building, skills acquisition and organisation for local strategy development and also help to ensure the attractiveness of rural areas for future generations.

(4) The three thematic axes were complemented by a methodological axis dedicated to the Leader approach, focussed on building local capacity for employment and diversification. The resources devoted to Axis 4 should have supported carrying out measures belonging to the priorities of the other axes, but also play an important role in improving governance, promoting participation and mobilising the endogenous potential of rural areas.

What is more, EU policy provided a catalogue of pre-defined measures from which the member states could choose those, which they considered to create the highest value added and for which they received Community financial support. The priorities had to be merged into multi-sectorial national rural development programmes and strategies. In this procedure it was stipulated that member states should maximise the synergies between and within the axes and should avoid potential contradictions. They should have also reflected on how to take into account other EU development strategies, in particular in the field of environment. This approach allowed EU cofinancing for rural development to focus on commonly agreed EU priorities for the three policy axes, while leaving sufficient power of decision at member states and regional level to find a balance between the sectoral dimension (agricultural restructuring) and the territorial dimension (land management and socio-economic development of rural areas (European Commission 2008).

\section{A short profile of the Romanian rural area}

To grasp the challenges faced by EU-created development strategies in the rural area of Romania, it is necessary to give at first a survey of the situation addressing the 
main demographic, social and economic aspects that define the post-Socialist rural area of Romania. Most of the statistical data are depicted from the last population census conducted in 2011 and the General Agricultural Census (GAC) performed in 2010, results which endorse the evolution tendencies characteristic for rural Romania of the last 25 years: scattered and ageing population, still rather low quality infrastructure (water supply, road network, sewage etc.) and fairly insufficient basic social infrastructure (health and education systems, finance and credit provision etc.) compared to urban areas. This affects quality of life, hinders economic development, increases out-migration, and worsens health and environmental issues. Rural economy is highly dependent on agriculture and forestry, with limited alternative activities and lower incomes than in urban areas.

Romania has a significantly higher rural population than the average of the European Union. The recent census of 2011 shows that $47.2 \%$ (NIS 2012) of the total population inhabits the rural area, i.e. $87.1 \%$ (NIS 2012) of the territory. Ageing and corresponding natural population decrease as well as emigration drive the pronounced current decline in population, enhancing several socio-economic disfunctionalities.

The National Plan for Rural Development established for the programming period 2007-2013 outlined the major economic and social implications caused by emigration. On the one hand remittances contribute significantly to the rural economy, and the main share goes into real estate (housing and land), with the ambition to improve the quality of life and to mitigate income risks. Remittances, together with attitude changes, contribute partly also to rural modernisation and development. Entrepreneurship is stronger among those who have worked abroad. On the other hand emigration also induces social costs, e.g. overstrains the intervention capacity of the social assistance system. Families are often dislocated and separated, and in many cases children are left with remaining family members, e.g. grandparents (GovernMENT of RoMANiA, Ministry of Agriculture and Rural Development 2008).

A large part of Romania's rural population is involved into agricultural activities, the agricultural sector being more important than in most other EU member states. $28.6 \%$ of the total population is employed in agriculture, forestry and fishery (EU average: $4.7 \%$ ) and contributes $6.5 \%$ (2011) to Gross Value Added (GVA). Although decreasing, the contribution of agriculture to GVA is still four times higher than the EU average of $1.7 \%$. Employment in the primary sector decreased slightly in recent years, with $31.6 \%$ in 2005 . However, productivity is very low, generally explained by the high number of agricultural workers, by their insufficient training as well as by the deficient public advisory network and dissemination of innovation and knowledge.

A large part of the population involved in agricultural activities is perceived as socially vulnerable due to their age, skills and income. Most of the farms are managed by older people with low qualifications and rather practical experience in agriculture. Agricultural activities are unattractive for a large part of the young generation, they are not regarded as a notable income source with perspectives. The number of young heads 
of agricultural units (under 35 years) is still low, even though it increased from $7.48 \%$ in 2005 to $11.71 \%$ in 2010 (NIS; România, Secretariatul Tehnic Central 2011) due to the measures of the programming period 2007-2013 designated to support young farmers. The General Agricultural Census of 2010 showed also that only $2.5 \%$ of the agricultural units were managed by trained farmers, while the EU average is $29.4 \%$ (România, Secretariatul Tehnic Central 2011). A lifelong learning system is an incipient level, specialised training is yet a basic eligibility requirement for many fund applications.

As shown above, farming continues to be the most important activity in rural areas and an essential source of income and self-supply for rural households. Yet size and productivity of the farms is defined by an accentuated dichotomy, the dualistic agrarian structure being the most challenging feature of Romania's agriculture (Bouniol 2013). In 1989, state farms and cooperatives established by the Communist party collectivising land and labour represented $90 \%$ of the Used Agricultural Area (UAA). The national agricultural system was based on large-scale production units with an average size of state farms around 5,000 ha. In the course of decollectivisation in the early 1990s former cooperatives and state farms were dismantled rapidly leading to fragmentation and privatisation of land. Cooperatives - two thirds of arable land in 1989 - were disassembled by the Land Trusts Law in February 1991. The land was divided into many small plots that were distributed to former owners and members of cooperatives. State farms were dismantled by Law No. 15/1990 and became commercial companies.

Thus, since 1990, Romania features a dualistic agrarian structure, organised around small-scale exploitation and individual plots on the one hand and large units of production operated by private or 'state-owned private corporations' on the other. According to the General Agricultural Census of 2010, 99.2\% of farms have no legal status as they are individual or family subsistence plots. They represent about 20 million plots of land and account for $56 \%$ of the UAA (in 2010). $44 \%$ of the UAA are owned by large agricultural companies with legal status.

The physical and economic size of farms differs strongly from the European average. In 2010, the average size of agricultural exploitations on national level was 3.5 ha, four times smaller then the European average of 14.3 ha UAA per farm. $71 \%$ of the total agricultural exploitations registered in 2010 had less than 2 ha of land. This is a clear indicator for the persistence of subsistence and semi-subsistence farms as a result of an inappropiate application of agricultural land reform in the early 1990s and the demographic structure. Fragmentation is even larger if one considers that the UAA of a farm is splitted into several smaller parcels located in different areas. This is a very important aspect, since a large share of these small-scale agricultural units are not eligible for support by the European Common Agrarian Policy (CAP). The average size of exploitations with legal status is 191 ha (RomÂNIA, SECRETARIATUL Tehnic Central 2011). The smallest farms have less then a hectare while the largest cover tens of thousands hectares. The total number of farms dropped by $2 \%$ compared 
to the data for 2002. This manifested itself in the decrease of the number of small, mostly subsistence and semi-subsistence holdings, which dropped by $14 \%$ while the largest commercial farms rose by 35\% (Bouniol 2013).

Peasant agriculture declines and large areas of agricultural land are fallow and not cultivated as small farmers are economically fragile and face many constraints on making any profit out of their activities. The reasons are numerous. Among them is the fact that European standards for obtaining subsidies are rather difficult to be achieved. In general, farmers do not have sufficient funds of their own to put up the required copayment, nor do they have access to bank loans to pay their share of the investment.

Animal husbandry is also decreasing. Results of the General Agrarian Census conducted in 2010 show a $30.9 \%$ decrease of cattle and $34.8 \%$ of pigs compared to 2002. However, the number of sheep grew by $15.9 \%$ and of goats even by $66.3 \%$ (România, Secretariatul Tehnic Central 2011). This hints at the growth of subsistence farming.

Several market-oriented small and middle-sized food-processing enterprises were created in the last decades, mainly with financial support provided by the EU predefined measures for rural development. Yet many other existing units perished as they could not comply with the new EU regulations or were incapable to compete on the market. The food-processing industry accounts more than 11,000 firms, contributing with $7 \%$ to the national GVA and employing $3.5 \%$ of the active population. Only $1 \%$ of enterprises have more than 250 employees, and two thirds are micro-enterprises with less than nine employees (European Commission, Press Release). Around 70\% of agricultural products are exported without processing. There is a substantial untapped potential to authenticate and promote local brands and products. Processing raw materials to traditional and innovative products, in this way creating jobs and added value, could contribute to the economic revival of rural areas.

Few small- and medium-size enterprises (SME) with non-agricultural profile (industry, services or tourism), only $18.1 \%$ of all SME, are located in rural areas, even though this type of enterprises is considered essential in creating new jobs and income in the rural area. Moreover, producer cooperatives are scarce, 153 registered in 2013.

Despite big investments into infrastructure development and upgrade also in the frame of the SAPARD pre-accession programme, rural areas in Romania are still conditioned by a significantly low coverage of quality infrastructure. According to the analysis of rural development reported in 2013 (Autoritatea de Management Pentru PNDR, Ministerul Agriculturi și Dezvoltări Rurale 2013), the water supply network (13.6\% of rural settlements connected in 2012) and the sewage system in the countryside show low percentages of coverage and inadequate quality. Services provided by heating plants register even a significant decline in the last years. Only $0.13 \%$ of the heat produced in heating stations was distributed in 2011 to rural housholds owing to production decrease or actual closure of several plants. 
Between 2005 and 2011, the distribution network of natural gasoline increased considerable, even in the rural area $17.3 \%$ more settlements being connected to the distribution system. Concerning electricity, in 2012 there were still 95 rural settlements without any power supply and another 1,992 with only partial coverage.

More important is the deficient road network with only around $7 \%$ of rural roads to be considered of adequate standard in 2011. Inappropiate road network in combination with scarce public transport possibilities is an impediment in accessing external educational, health and other services. This situation affects also incoming service providers, basic social infrastructures being insufficiantly present. A proper road network could contribute to an improvement of quality of life as well as to socioeconomic upgrade.

Great disparities in wealth, opportunities, education and skills prevale in Romania. The 2011 census points out that $29.4 \%$ of the total Romanian population is exposed to poverty and/or severe social exclusion, significantly exceeding the EU-27 average of $8.8 \%$ (Eurostat). Almost three fourths of poverty-affected population resides in the rural area, poverty persisting in the Romanian countryside.

All these socio-political, economic and environmental transformations as well as the changes in the value system of former traditional communities challenge the identity of the Romanian village and its material and immaterial cultural heritage.

\section{The Rural Development Plan of Romania for the programming period 2007-2013}

EU accession in 2007 meant a whole new set of issues and a new framework to work with and to solve these issues. The point of departure in the rural area required rather to find a balance between agriculture and environment as well as communityfriendly long-term economic growth. In compliance with the profile of the country's rural area, the National Plan for Rural Development of Romania for the programming period 2007-2013 identified several key challenges elaborating the following overall objectives (Government of Romania, Ministry of Agriculture and Rural DevelopMENT, 2008):

- Facilitate transformation and modernisation of agriculture and forestry production and processing sectors, improving competitiveness and ensuring environmental sustainability;

- Maintain and enhance rural environment;

- Facilitate movement of labour from agriculture to other sectors and ensure adequate economic and social conditions for the rural population. 
On the basis of the general aims, main priorities were identified for each of the three core policy objectives. Improving skills and management capacity through support for vocational training and the provision of farm advisory and extension services was one of the objectives of the first axis. The same chapter included measures for improving the competitiveness of the farming sector through farm investments, support for semi-subsistence farms to become more commercial and improvements in infrastructure. Furtheron, procedures for restructuring and modernisation of processing and marketing of agricultural and forestry products were integrated into the first core policy objective. The European Agricultural Fund for Rural Development (EAFRD) allocated $43.95 \%$ of the total funds to Axis 1 for the above-mentioned measures.

The priorities under Axis 2 included maintaining sustainable farming in mountain and other disadvantaged areas to preserve the environment, avoid land abandonment and address problems such as soil erosion. Following the same core aim further procedures were intended to maintain and enhance environmental benefits generated by traditional extensive farming systems of High Nature Value (HNV). Axis 2 targeted also the protection of endangered bird species and their habitats as well as afforestation of agricultural land. Around a quarter $(26.05 \%)$ of the EAFRD budget were assigned to the priorities of this Axis.

Axis 3 adressed mainly economic issues, such as diversification of the rural economy and job creation stimulated through support for micro-enterprises, tourist facilities and attractions. This core policy objective incorporated also large village renewal and development measures, encouraging also communities to submit integrated projects covering a range of physical and social infrastructure elements to improve village life. $27.4 \%$ of the EAFRD resources were dedicated to this sort of measures.

Axis 4 received $2.6 \%$ of the EAFRD funds. With this financial support the Leader approach aimed to improve local governance capacity and to promote local development. One of the major goals was to implement local strategies by Local Action Groups (LAG) and to include cooperation projects with other Leader groups.

A list of pre-defined measures was available to be applied in order to achieve the designated goals of each development priority.

\section{5 "The principle is good. The way it is implemented is bad."}

The title of the paper and of this chapter reflects a conclusion of an expert in rural development strategies related to the Leader approach, yet valid for the EU Rural Development Policy in general. To illustrate this conclusion, this chapter depicts some of the above-mentioned main priorities of the four development axes displaying a series of difficulties the EU Rural Development Policy and its strategy faces in Romania. The 
chapter emphasises mainly the situation of small farmers and lists also some of the possible remedies developed by various organisations of the civil society.

One of the priorities of Axis 1 is enhancing skills and management capacities of farmers through farm advisory and extension services. The public advisory network worked in 2010 with 850 employees (MADR 2013), 350 of them in the agriculture chambers on county level (NUTS-3), the rest in local consultancy offices. Considering that in 2011 Romania had 2,861 communes and 12,957 villages, it is obvious that effectively advicing farmers is impossible.

Of course, all important information regarding development priorities, measures, application formalities or founding opportunities is listed on the webpage of the Ministry of Agriculture and Rural Development (MADR). Yet, this major data source is not available for most of the farmers, since in 2012 only 23\% (MADR 2013) of the countryside households had internet access. Taking into account that a large share of the agricultural population is elderly (in 2007 44\% were more than 64 years), has a lower educational level, a narrower skill base and is probably not familiar with an online data source, this multiplies the problem.

Difficulties occur not only in accessing information but in accessing measures under the National Plan for Rural Development as well, which requires the knowledge of how to apply for those funds, all norms written down in the guidelines for applicants. Even simple ones consternate small farmers and producers. In the case that some of them actually cope with the norms, they end up struggling with the stiffest institutional bureaucracy of the authorities supervising and implementing the measures.

Obviously, it is recommendable to enhance information transmission and to adapt the system to the realities and constraints of the Romanian rural area. The civil society is fairly active in this concern and ignites several measures to support mainly small farmers and producers in their endeavour to access and make use of the possibilities offered by the Rural Development Policy. They facilitate farmers' training for capacity building through workshops. Other fruitful measures are to convene meetings with farmers, individually or in groups, with associations, communal authorities and other community groups on a regular basis and to invite key speakers to current issues of interest. To overcome the difficulties caused by the technical terminology for most farmers, NGOs working in this field develop and update continuously a series of publications and practical guides to help farmers and producers to understand the minimum requirements for receiving EU grants and to avoid excessive regulations.

Just to mention one concrete tool for supporting small farmers: ADEPT Foundation $^{2}$ developed an intelligent SMS system to improve access to Common Agrarian Policy opportunities for small farmers. As they explain (Fundatia AdEPT), the idea behind the SMSFamilyFarms is to keep the thousands of small farmers, most of whom have no internet access, continuously updated about rural development

2 http://www.fundatia-adept.org/ 
measures and to improve their economic viability. The innovative idea is to transform information, often in a technlogical language hard to be understood by the farmers, into short and relevant messages and to disseminate it to a large number of farmers immediately. To benefit from this service, interested farmers need to register. Based on the information they provide and their activity profile, they receive relevant news on a regular basis on legislative changes, national and international fairs, seminars, courses, subsidy payments, reminders of new funding opportunities and deadlines of funding application, etc.

Besides advisory services, this priority of Axis 1 focuses also on vocational training to improve skills and management capacity of the rural population. Experienced people engaged in rural development disclose the complicated structure and overloaded curricula of many vocational trainings not serving the purpose and lacking useful practical information. Better structured trainings, tailored to the needs of the target groups, would be more suitable for skill and knowledge transfer, especially in the support for businesses.

Improving the competitiveness of the farming sector is a further pillar of Axis 1. Reports repeatedly attribute the low productivity of Romanian agriculture to the predominance of small-scale subsistence farms. However, subsistence farming includes also informal networks that supply family members in nearby towns and cities and are in this way more significant socially and economically than official statistics show.

Yet, Romanian governmental policies urge to increase the agricultural competitiveness in order to compete with European and international markets, especially supporting measures for merging and reducing the number of agricultural exploitations, and are openly directed towards the development of competitive large-scale agro-export agriculture. Such policies encourage the exodus from farming and support land concentration. Agricultural land consolidation ambitions under the current political and normative situation, complemented by favourable rural socio-economic dynamics can lead to land grabs ${ }^{3}$ to the detriment of small farmers. Both Romanian and foreign corporations persuade government authorities to steer legislation and development programmes in their favour exploiting the vulnerability of the population and institutional weaknesses (BounIOL 2013). Given the scarce support for peasant agriculture and coherent rural development, the socio-economic context of rural areas is attractive for large investments. Foreign or Romanian agro-industrial corporations settle legally through lease or purchase of land. The rural population, mainly elderly and vulnerable, is in general enthusiastic, when massive investments arrive, and agrees to lease land in exchange for additional income. Taking advantage of uninformed people, unfamiliar with administrative procedures, contracts can actually cause the loss of land. The growing phenomenon of land grabbing is pushing up land prices, putting them be-

3 Land grabbing is understood as using large-scale capital to capture control of physical resources as well the power to decide how and for what purposes they will be used. Generally speaking it is socially, economically and environmentally destructive. 
yond the reach of smaller local farmers. Companies can even achieve control of public resources (water) or prevent the development of pastoral activities as well as reshape cultural and historical landscapes in the process of land concentration and consolidation (Bouniol 2013).

The interest of foreign investors is not only nurtured by the fertile soils and the large regions particularly appropriate to intensive agriculture, but also by the relatively low price of land compared to western European countries and by the massive subsidies directed towards large-scale agriculture by the government and the EU. Since joining the EU in 2007, Romanian farmers have benefited from Common Agrarian Policy direct subsidies, but these were very unevenly distributed: Less than $1 \%$ of farms, but with more than 500 ha, received half of the subsidies and the remaining $99 \%$ of farms shared the other half (Bouniol 2013). Large farms benefitted most of the subsidies, smaller ones, actually needing them more, got less. Besides this, Romanian farmers can also receive funds from the European Agricultural Fund for Rural Development (EAFRD).

These aspects indicate that land grabbing, even as a side effect of governmental development strategies, is rather weakening rural economies and prevents the development of a dynamic rural sector.

Another major problem is the difficulty of processing and marketing rural products. The National Plan for Rural Development defines as a priority the restructuration and modernisation of processing and marketing of agricultural and forestry products. A considerable number of small farmers and producers, however, cannot benefit from these measures. Several associations and organisations - concerned about ecologically, economically, culturally and socially sustainable development - create and maintain partnerships between consumers from urban areas and small farmers from the surrounding rural area practicing natural agriculture. These actions create and diversify income possibilities and contribute to landscape maintenance.

In Romania traditional land management and extensive farming systems created high nature value ecosystems located mainly in the Carpathians [Carpatiii] and in Transylvania [Ardeal]. On the one hand these semi-natural ecosystems proved to have a high species and habitat diversity, but on the other hand the traditional and/ or extensive land management usually overlaps with poorer areas and with semisubsistence farming. The priority of Axis 2 - to maintain sustainable farming in mountain and other disadvantaged areas in order to preserve the environment, avoid land abandonment and address problems such as soil erosion - emphasises mainly these areas.

High Nature Value Farmlands (HNVF) are considered lands of predominantly agricultural use where the high biodiversity is conserved presenting features of a particularly valuable or unique landscape with special conditions for the persistence of ecosystems, communities and species. The dominant characteristic of HNV farming is 
its low intensity. A significant presence of semi-natural vegetation is also essential. In situations where the proportion of land under semi-natural vegetation is reduced, a high diversity of land cover (mosaic) under low-intensity farming may enable significant levels of biodiversity to survive (European Commission, Agriculture and Rural Development, European Evaluation Network for Rural Development 2009).

HNVF provide living space for a large number of globally and regionally endangered species and have a great importance for national food security and rural wellbeing. Estimated 3.32 million hectares (TÁnczos 2011) of Romania's agricultural land can be classified as area where is most likely that HNV systems are present. These areas with the highest farming-related nature values are managed mainly by small-scale subsistence and semi-subsistence farms. There is also a significant overlapping with less-favoured areas, nationally protected areas or Natura-2000 sites. Approximately 2.4 million ha of Romania's semi-natural grassland is classified as of High Nature Value. About three quarters of it are pastures and hay meadows.

Considered as of major importance, Romania has taken the needs of HNV farmland into account in its Rural Development Plan for 2007-2013 in the shape of several sub-measure agri-environment project payments (TÁNCZOS 2011), e.g. management of HNV grasslands, support for traditional farming practices, support for grasslands for important birds and green cover, ecological agriculture (GOVERNMENT OF Romania, Ministry of Agriculture and Rural Development 2008). In Romania there are around 3.4 million subsistence farms with an average size of 1.17 ha and almost a million semi-subsistence farms (TÁnczos 2011). Yet, only farmers owning more than 1 ha of land in parcels of more than 0.3 ha are eligible for Common Agrarian Policy support. This means that most of the farms are exluded from any kind of support. At national level, estimations about semi-subsistence farmers eligible for support by the 2007-2013 Rural Development Programme amounted only to 85,000. Support equaled 1,500 Euro/year for five years and farmers were also eligible for free advisory services to prepare application documents. The operational objectives of these measures were to maintain grasslands of high nature value, assure adequate management of habitats for important species, ensure water and soil protection and conserve natural resources.

Due to the strong link between HNV farming and marginal areas - the same combination of factors can lead to marginal farming and HNV farming - the HNVFs can benefit also from the two measures Romania has in it's rural development programme aimed at Less Favoured Areas (LFA) $)^{4}$ a measure regarding mountain

\footnotetext{
$4 \quad$ In areas designated as „less-favoured“, agricultural production or activity is more difficult because of natural handicaps, e.g. difficult climatic conditions, steep slopes in mountain areas, or low soil productivity. Due to the handicap to farming there is a significant risk of agricultural land abandonment and thus a possibility of loss of biodiversity, desertification, forest fires and the loss of highly valuable rural landscape. To mitigate these risks, the Less Favoured Areas (LFA) payment scheme is an important tool, implemented by all the Member States although it is not a compulsory measure (European Commission, Agriculture AND Rural Development).
} 
regions and a measure considering other LFAs and areas with specific natural handicaps.

In the long run, LFA support alone will not have the capacity to ensure HNV farming survival, but it provides for an important contribution. In fact, in farmed, semi-natural landscapes, survival of biodiversity depends on continued management by local people. Small farmers and the HNV-farmed landscapes with rich biodiversity created by the traditional land management are lately threatened by social and economic factors, especially under the drive for competitiveness in the EU and global markets. If traditional land management no longer offers a livelihood to small farmers, they quit, causing the collapse of the whole system and the loss of biodiversity. Breakdown of markets - especially milk - strong competition by imports and sudden additional burdens by EU hygiene regulations determined already the decline in cattle and the renunciation of moweing $50 \%$ of hay meadows. Changes in farm structure and village abandonment also leads to the loss of traditional farmland management.

More recently, policy makers have increasingly appreciated the wider social, economic and environmental benefits of semi-natural man-made landscapes and farming systems and are determined to protect and maintain them. Yet, while agrienvironment aims to maintain the environmental value of the area, the measures introduced have in some cases been counter-productive. For example, the setting of a single mowing date reduces the mosaic pattern of long and short grass on which many species thrive. When we want to give these landscapes and communities an economic future and relevance without sacrificing their sustainability and productivity, an innovative approach is required. Local projects are more important for maintaining HNV farming. For example, the Pogány-havas Microregion Association supported by local councils, NGOs and entrepreneurs' works on a range of projects to increase local incomes, preserve the region's cultural heritage, and record and conserve the natural environment. Similar work is carried out by the ADEPT Foundation with an integrated programme linking economic and social benefits with biodiversity conservation and raising local capacity for good management in the future. ADEPT's programme focuses on the study of habitats/species and on the design of management measures to conserve biodiversity while getting local support by involving local people in design and execution of practical management measures. They develop models that could be implemented also in other regions focusing on local branding based on environmental and cultural values, on promoting environmental services through farmers' associations and promoting organic, HNV and traditional concepts.

However, many of these initiatives of integrated programmes for the sustainable living in biodiversity-rich areas are endangered when development measures counteract and thwart each other in their implementation.

Not only the HNV farmlands are at risk. Industrialised agriculture strongly contributed to the drastic reduction of diversity and genetic erosion not only in Romania, but worldwide. Mainly old and local varieties of crops have been most 
affected, in favour of modern species. Romania boasts still a significant number of traditional species. Traditional old seeds, developed under the influence of natural selection, are a very precious heritage. The Eco ruralis grassroots association - made up of small farmers who practice organic and traditional farming based on environmentalconscious principles - explains in a report from 2011 concerning conservation of vegetable traditional resources that ,in order to use a seed in the European Union (Directive 98/95 EEC transposed into Romanian legislation by L266/2002), it must be stated that variety is registered in an official catalog. The DUS Criteria (Distinction, Uniformity and Stability) cannot apply to local varieties and involves high cost for registration and compulsory chemical treatment. These conditions are downgrading the local traditional seeds that are naturally adapted to organic farming and traditional history. By extension, the regulation in place prohibits the marketing of traditional seed varieties and associated traditional seeds have no access on the market." (ECO RURALIS ROMANIA)

Large-scale agricultural enterprises use almost exclusively modern and hybrid seeds, also promoted by state policy argueing with raised competitive yield results. Thus the circuit of traditional seeds remains informal within local communities. And this circuit is vulnerable because of the difficulty to maintain continuity in transmitting knowledge on reproduction, cultivation, processing, etc., held by a few community members, who are usually elderly. Aging rural population and lack of interest to engage the next generation in traditional agriculture, who do not see an economic perspective, is another reason for concerns.

Eco ruralis promotes agroecology and encourages to use, multiply and distribute traditional seeds, the pursuit of strict biosafety regulations (without genetically modified organisms). In addition, it advocates for the preservation of food sovereignty in Romania and the respect for consumer health.

Another significant initiative to preserve genetic diversity comes from the Civitas Foundation, which emphasises the traditional fruit varieties. The Székelygyümölcs (Fruits of Seklerland) programme is a regional community-building development measure. It supports farmers and small producers in maintaining traditional orchards and marketing their products. In this way it contributes to the sustainability of their communities and environment and creates jobs and income possibilities on the local level (SzÉKELYGYÜMÖLCS). The activities include trainings, workshops, studies about the genetic diversity of traditional fruit sorts and also marketing and promotion of goods made of tradtional fruits. The Foundation established also a facility where goods can be produced respecting the EU regulations concerning hygienic and sanitary issues. They also offer assistance in starting and conducting businesses by promoting entrepreneurship in the rural area.

Diversification of the rural economy and job creation is encouraged through support for micro-enterprises, as well as tourist facilities and attractions as a main priority of Axis 3 . 
The crucial problem faced by micro-enterprises is stiff institutional bureaucracy. Romanian legislation applies the same regulations for large and micro-enterprises restraining entrepreneurship of possibly interested people in rural areas. For microenterprises it is nearly impossible to comply with all excessive requirements, although on EU level exist simplified procedures for them. The already mentioned ADEPT Foundation built a model food processing unit in a village primarily for demonstration and training. It produces also local income since locals can produce jams and other products in accordance with the EU sanitary and hygienic regulations and can offer them for sale.

Another prioritiy of Axis 3 is village renewal and development. This measure usualy concerns major infrastructure developments such as water and energy supply or sewage systems. Innovative approaches to rural development originating from the affected communities encounter various legal, financial or bureaucratic challenges. The only biological sewage treatment system in Romania, e.g., is located in Viscri/ Deutschweißkirch, a small remote village of about 450 inhabitants. Locals initiated the project. Yet, they had a long battle to obtain all the permits and certifications, one of the major impediments being the fact that Romania has no legal framework concerning this kind of facilities.

Another difficult case is road infrastructure due to the fact that jurisdiction over the various roads is split. Communes cannot repair their road network, since it is under several jurisdictions.

Axis 4, the methodological axis of the Development Programme, is designed to help rural actors to develop an area by using its endogenous development potential. ${ }^{5}$ It aims at improving local governance capacity and promoting local development, encouraging the implementation of integrated, high-quality and original strategies for sustainable development. The Leader approach has a strong focus on partnership and networks of experience exchange. Local Action Groups (LAG) are the main elements of implementation. Their responsibilities include the development of local strategies, supporting stakeholder networking and the appraisal and approval of individual Leader projects.

In 2011, the National Development Programm for Rural Areas lists 82 LAGs established in the rural area of Romania. Generally speaking it is too early to evaluate the efficiency of this development strategy, yet some preliminary observations can be made. The LAGs of active microregions with a stronger entepreneurship previous to the establishment of these new entities perform better. LAGs in less active microregions do not demonstrate a better local governance capacity.

This participatory development strategy was created as a bottom-up process taking into consideration local needs and potential and actively involving a representative cross-section of the local community. With the essential contribution of

5 http://enrd.ec.europa.eu/enrd-static/leader/en/leader_en.html 
the community the LAG should carry out an integrated and multi-sectoral area-based Local Development Strategy (LDS). There were cases mentioned, where the LDS was prepared by third parties without the involvement of the affected community. In other situations, even though these strategies exist, they are not applied. The designation of the LAG was rather a top-down process and their efficiency is constantly constrained by overloaded bureaucracy and payments for maintenance.

It is a proven fact that local and regional development plans could be more successful if the population affected is on the one hand aware of the landscape's relevance and its potential and on the other understands the importance of the community in the process of community management. Due to various socio-cultural factors the society is often reluctant as regards active participation in decision making and execution of commonly agreed measures. A widespread mentality of dependency, frustration, distrust in the political administration on one hand and expectations that communes and politicians have to solve problems on the other hinder initiatives and entrepreneurial spirit.

\section{Conclusions}

It is well known that in case of improper and uncoordinated application existing EU policies can potentially counteract and thwart each other in their implementation, to the detriment of landscape quality, environment, economy and society. The paper presented a few representative examples of how the former National Plan for Rural Development for the programming period 2007-2013 struggled and in many cases failed in maximising synergies between and within the development axes and in avoiding potential contradictions.

A certain improvement of living standards in the Romanian countryside in the last decades is not contested, yet an insufficiently defined development vision hindered comprehensive and more efficient sustainable progress. It has also to be said that several principles of the EU policy are rather alien to local mentality or not suitable to rural Romania. Moreover, an overloaded bureaucracy, stiff regulations with an approach of being "more Catholic than the Pope" and the complexity of guidelines are major burdens for a successful performance of development measures. A main aspect of rural development would also be the application of the subsidiarity principle, yet Romania lacks the necessary instruments or even the political will for ist implementation and, generally speaking, low interest of the population in participatory development strategies is not helpful either.

A creative rural development policy based on integration, open to new developments could lead to constructing or reconstructing attractive landscapes, would stimulate economy and revive society. Mainly in the rural areas where 
traditional methods of agriculture and land use are on the way to be or were already abandoned, landscapes are deteriorating due to a lack of human actions. These areas need development strategies to avoid complete fallowing. Appropriate and responsible management could point out the activities, which will economically revive a given area and at the same time preserve and protect the most valuable characteristics and values of the landscapes.

The importance of High Nature Value (HNV) farmlands is not yet well understood, their added value for local economies is not entirly recognised and HNV farmers are often socially marginalised. A one-size-fit-all-approach to agri-environment does not realy work. Instead, measures should be adapted to the specific requirements in the area and target specific outcomes. Moreover, historically based generally established Common Agrarian Policy payments do not provide adequate support for farmers producing environmental public goods. Agri-environment schemes provide significant benefits but need to be accessible for small-scale applications and may be insufficient to make businesses commercially viable - they only support certain practices. Locally targeted projects are essential and actually more efficient to focus attention on what is needed to maintain HNV farming.

Civil society organisations working on site and facing many challenges in their development endeavours can contribute to the improvement of policies. Their strength of influencing policy comes from the fact that their proposals are mainly based on practical experience through innovative projects they carry out. In this way they produce clear technical justifications for proposals offering reasonable and practical solutions rather than simple demands to policy makers.

Agriculture continues to be a defining feature of the Romanian countryside and its population. Concrete examples show that the isolated pursuit for higher yields and foreign direct investment does not lead to sustainable agricultural systems. Instead of turning away from the agrarian nature of the country, a rather complex development strategy including also small farmers and building a marketing strategy for natural farming and its products would be a possible path to strive for respectful and fruitful combinations of protection and development.

A large share of the rural population, mainly small farmers, were nearly totally excluded from the benefits of the National Plan for Rural Development, not complying with the minimum requirements or not being able to access the measures. Analysis affirms that the new National Plan for Rural Development for the programming period 2014-2020 denotes a more connected vision concerning the necessities of Romanian agriculture placing more emphasis on family farms. The current policy in force enables family farms to be more competitive on the market. It has created also a new subthematic programme concerning the fruit-growing sector and there are incentives offered for young people to get involved in agriculture. Worth mentioning is also the cooperation measure, which allows to attract individualised support in order to create market-oriented agricultural associations and cooperatives. These initiatives show 
that the experiences of the expired programming period could improve the current development plan.

\section{References}

Autoritatea de Management pentru PNDR, Ministerul Agriculturi \$̦ I DezvoltăRi Rurale (eds.) (2013), Analiza socio-economică în perspectiva dezvoltării rurale 2014-2020 $<$ http://www.madr.ro/docs/dezvoltare-rurala/programare-2014-2020/analiza-dezvoltariirurale-agricultura-iulie-2013.pdf> (accessed 24/10/2014)

Bouniol J. (2013), Scramble for land in Romania. Iron fist in a velvet glove. In: Transnational Institute (TNI) for European Coordination Via Campesina and Hands off the Land Network (ed.), Land concentration, land grabbing and people's struggles in Europe, pp. 146-167. Transnational Institute (TNI) for European Coordination Via Campesina and Hands off the Land network $<$ https://www.tni.org/files/download/land_in_europe_1.pdf $>$

Eco RURalis Romania < http://www.ecoruralis.ro/web/en/Publications/> (accessed 16/11/2014).

European Commission (ed.) (2008), Fact Sheet. EU Rural Development Policy 2007-2013<http:// ec.europa.eu/agriculture/publi/fact/rurdev2007/2007_en.pdf> (accessed 23/10/2014)

European Commission (ed.) (2011), CHAPTER 4. Overview of the EU Rural Development Policy 2007-2013 <http://ec.europa.eu/agriculture/statistics/rural-development/2011/ ch4_en.pdf> (accessed 24/10/2014)

European Commission, Agriculture and Rural Development < http://ec.europa.eu/agriculture/ rurdev/lfa/index_en.htm> (accessed 04/02/2015)

European Commission, Agriculture and RuRal Development < http://www.un.org/esa/agenda21/ natlinfo/countr/ec/agriculture.pdf> (accessed 09/01/2015)

European Commission, Press Release Database $<$ http://europa.eu/rapid/press-release_MEMO08-103_en.htm?locale $=$ en $>($ accessed 24/10/2014)

Fundatia AdEPT (ed.) <http://www.fundatia-adept.org/innovation/SMSFF?set_lang=en> (accessed 18/09/2014)

Government of Romania, Ministry of Agriculture and Rural Development (ed.) (2008), National Rural Development Programme 2007-2013, consolidated version 21 of July 2008 $<$ http://old.madr.ro/pages/dezvoltare_rurala/nrdp_consolidated_version_2008_07_21. pdf $>$ (accessed 09/01/2015)

Ministerul Agriculturi și Dezvoltări Rurale (MADR) (ed.) (2013), Analiza socio-economica a spatiului rural romanesc <http://www.madr.ro/docs/dezvoltare-rurala/Descrierea generala_a_situatiei_economice_actuale_4_11_2013.pdf $>$ (accessed 22/10/2014)

Ministerul Agriculturi și Dezvoltări Rurale (MADR) (ed.), Autoritatea de Management pentru PNDR: Analiza socio-economica in perspectiva dezvoltarii rurale 2014-2020 $<$ http://www.madr.ro/docs/dezvoltare-rurala/programare-2014-2020/analiza-dezvoltariirurale-agricultura-iulie-2013.pdf $>$ (accessed 24/10/2014)

Ministerul Agriculturi și Dezvoltări Rurale (MADR) (ed.), Programul Naţional de Dezvoltare Rurală 2007-2013, versiunea consolidată decembrie $2012<$ http://old.madr. ro/pages/dezvoltare_rurala/Program-National-de-Dezvoltare-Rurala-versiunea10consolidata-decembrie-2012.pdf> (accessed 20/10/2014) 
National Iinstitute of Statistics (NIS) (ed.) (2012) <http://www.insse.ro/cms/en> (accessed $04 / 02 / 2015)$

Nature's Voice, Birdlife International (eds.) (2011), High Nature Value Farming. How diversity in Europe's farms systems deliver for biodiversity <http://www.efncp.org/ download/HNV-farming.pdf $>$ (accessed 10/02/2015)

Network for Rural Development (eds.) (2009), The Application of the High Nature Value Impact Indicator 2007-2013 <http://ec.europa.eu/agriculture/rurdev/eval/hnv/guidance en.pdf> (accessed 04/02/2015)

România, Secretariatul Tehnic Central (ed.) (2011), Recensąmântul General Agricol 2010, Rezultate Provizorii $<$ http://www.fao.org/fileadmin/templates/ess/ess_test_folder/World_ Census_Agriculture/Country_info_2010/Reports/Reports_4/ROM_ROU_PRE_ REP_2010.pdf $>$ (accessed 30/10/2014)

SZÉKELYGYÜMÖLCS < http://www.szekelygyumolcs.ro/index.php/2014-03-24-20-29-20/a-projektbemutatasa $>$ (accessed 16/11/2014)

TÁnczos B., The importance of High Nature Value Farming - Views from Romania $<$ http:// www.efncp.org/download/tanczos.pdf $>$ (accessed 11/11/2014) 